\begin{tabular}{|l|l|l||}
\hline \multicolumn{2}{|c|}{ PublisherInfo } \\
\hline \hline PublisherName & $:$ & BioMed Central \\
\hline \hline PublisherLocation & $:$ & London \\
\hline \hline PublisherImprintName & $:$ & BioMed Central \\
\hline \hline
\end{tabular}

\title{
Origin of AIDS: debate intensifies
}

\begin{tabular}{|l|l|l||}
\hline \multicolumn{2}{|c|}{ ArticleInfo } \\
\hline \hline ArticleID & $:$ & 3765 \\
\hline \hline ArticleDOI & $:$ & $10.1186 /$ gb-spotlight-20000914-01 \\
\hline \hline ArticleCitationID & $:$ & spotlight-20000914-01 \\
\hline \hline ArticleSequenceNumber & $:$ & 202 \\
\hline \hline ArticleCategory & $:$ & Research news \\
\hline \hline ArticleFirstPage & $:$ & 1 \\
\hline \hline ArticleLastPage & $:$ & 4 \\
\hline \hline & & RegistrationDate : 2000-09-14 \\
\hline ArticleHistory & $:$ & OnlineDate \\
\hline \hline ArticleCopyright & $:$ & BioMed Central Ltd2000-09-14 \\
\hline \hline ArticleGrants & $:$ & \\
\hline \hline ArticleContext & $:$ & 130591111 \\
\hline \hline
\end{tabular}


LONDON, September 12 (Science Analysed). Yesterday the Royal Society of London,bravely attempting to inject some scientific order into a debate on the origin of AIDS, found itself in the midst of one of its hottest conflicts yet.

"We are being accused of lying" said Stanley Plotkin, of the Universityof Pennsylvania. Plotkin has spent a year with writer Ed Hooper's book, TheRiver, investigating its argument that trials of an oral polio vaccine, CHAT, transmitted the chimpanzee virus SIV to the world in the Congo in 1957-59, thereby launching the AIDS epidemic when SIV evolved into HIV in the human population. "After a year's work, I'm satisfied the things alleged never happened."

Ed Hooper, also on the podium at the end of the first of two days ofpresentations on the hypothesis, said "I have been deeply unimpressed by what Plotkin and Koprowski [Hilary Koprowski of Thomas Jefferson University, with Plotkin the creator of CHAT] said today," said Hooper. "I have heard no substantial answer to any of the central tenets in The River."

So the key protagonists stated their positions at the end of the firstday of presentations on the CHAT hypothesis even more firmly, it seems, than they would have done at the beginning.

The problem has been that, until yesterday, the direct evidence oneither side seemed to be contradictory reports of statements byscientists and technicians about whether chimpanzee kidneys were everused as a substrate to create CHAT, and if that was used in thevaccination of a million or so Africans, some 100,000 of whom might havebeen over five years old.

It is agreed that HIV was a zoonosis, and that HIV1-M, the majorHIV strain, is most closely related to chimpanzee SIV,but there all agreement ends.

But why didn't yesterday's announcement by the Wistar Institute, wherePlotkin and Koprowski worked, that three independent laboratories hadfound "no AIDS-related viruses or chimpanzee DNA ... in 1950s-era poliovaccine," and that the mitochondrial DNA present was of macaques, notchimpanzees, stop Ed Hooper in his tracks?

In the Wistar press release Claudio Basilico of the New York MedicalCenter, head of the Wistar external AIDS/Poliovirus Advisory Committeethat organized the testing, says that "there is nothing in the resultsfrom these tests to support the theory that HIV entered the humanpopulation during the late 1950s poliovirus clinical trials in Africa."

But, Hooper claimed to BioMed Central, these few millilitres of sevensamples of CHAT vaccine held in the fridges at Wistar "were of unknownprovenance. I don't know if they were used in Africa." Documentationwas poor, he said. Even Claudio Basilico, speaking with BioMedCentral yesterday, described the 1950s vaccine work as having been donewith a certain "disinvolto - as we say in Italian." (Translated intoEnglish the word means 'carefree'.) "But after all this was 40 yearsago" said BioMed Central. "Yes, but not 400," said Basilico. 
Hooper, Plotkin and Koprowski agree that one of the samples, labelledCHAT-13, was used in Africa. But according to Hooper it was also used inPoland, and was the fridge sample the Polish version? Hooper claims thesame pool of vaccines was passaged through different substratesin different laboratories - something Plotkin claims would be "crazy."Hooper also claims the Wistar results to be irrelevant, because some ofthe CHAT vaccine used in Africa may have been made in Africa and Belgium onchimpanzee substrates, something Plotkin and Koprowski vehemently deny -they say they used monkeys from the Phillippines and India, and made thevaccine in America.

At the press conference, Koprowksi said that while the vaccine used inAfrica "was used up", as Hooper had claimed, the samples tested atWistar were the remants of a seed lot. Were they the same as what wasused in Africa, Koprowski was asked? "Exactly" he said. And he pleaded:"You know at that time an aggressive attack on polio was mandatory.It was considered like AIDS is now."

So the debate rolls on. 'Scientific facts' that will close this caseseem extremely hard to come by, and the argument continually falls backon claim and denial; but the Royal Society meeting is certainlystruggling to find what science it can.

Apart from the purely verbal claims and counterclaims, of which thereare legion, other potentially testable matters so far being discussed atthe meeting, and all contested by Hooper either factually or for theirrelevance are:

- that the chimpanzee SIVs most closely related to HIV come from a West CentralAfrican species, not the Eastern African species most likely to havebeen used (if at all) for CHAT; - that SIV does not culture in kidney cells, and would be destroyedby the vaccine production process; - that tracing the common point of origin of the many HIV varieties pointsto a date of divergence between 1910 and 1940, and according to onestudy, to a date earlier than 1950 with $95 \%$ confidence; - that Hooper's map of the geographic and temporal coincidence of thefirst cases of AIDS and the delivery of CHAT is mistaken andstatistically insignificant (for example, says Plotkin, there were casesin Katanga province where no vaccine was given).

However, when BioMed Central asked Ed Hooper if there was any evidencethat he would accept as destroying his claim, so ending the debate, hesaid just one thing would do: "finding HIV-1 M in a human sample priorto 1955."

\section{References}

1. The Royal Society, [http://www.royalsoc.ac.uk/]

2. BioMed Central, [http://www.biomedcentral.com]

This PDF file was created after publication. 
(c) 2009-2013. SPi Global, Chennai, India. All rights reserved. 